\title{
CONTRACTUAL RIGIDITY AND POLITICAL CONTESTABILITY: REVISITING PUBLIC CONTRACT RENEGOTIATIONS
}

\author{
Jean Beuve \\ Marian W. Moszoro \\ Pablo T. Spiller \\ Working Paper 28491 \\ http://www.nber.org/papers/w28491 \\ NATIONAL BUREAU OF ECONOMIC RESEARCH \\ 1050 Massachusetts Avenue \\ Cambridge, MA 02138 \\ February 2021
}

We are thankful to Fritz Bachmair, Mikhail Freer, and Lorena Rivero del Paso for valuable comments and suggestions. The views expressed herein are those of the authors and should not be attributed to the IMF, its Executive Board, its management, or the National Bureau of Economic Research.

NBER working papers are circulated for discussion and comment purposes. They have not been peer-reviewed or been subject to the review by the NBER Board of Directors that accompanies official NBER publications.

(C) 2021 by Jean Beuve, Marian W. Moszoro, and Pablo T. Spiller. All rights reserved. Short sections of text, not to exceed two paragraphs, may be quoted without explicit permission provided that full credit, including $(\mathrm{C}$ notice, is given to the source. 
Contractual Rigidity and Political Contestability: Revisiting Public Contract Renegotiations Jean Beuve, Marian W. Moszoro, and Pablo T. Spiller

NBER Working Paper No. 28491

February 2021

JEL No. D23,D72,D73,D78,H57

\section{ABSTRACT}

We present a model of public procurement in which both contractual flexibility and political tolerance for contractual deviations determine renegotiations. In the model, contractual flexibility allows for adaptation without formal renegotiation while political tolerance for deviations decreases with political competition. We then compare renegotiation rates of procurement contracts in which the procurer is either a public administration or a private corporation. We find robust evidence consistent with the model predictions: public-to-private contracts are renegotiated more often than comparable private-to-private contracts, and that this pattern is more salient in politically contestable jurisdictions. The frequent renegotiation of public contracts results from their inherent rigidity and provides a relational quality of adaptability to contingencies in politically contestable environments.

Jean Beuve

Centre d'Economie de la Sorbonne

Bureau 226

106-112 boulevard de l'Hôpital

Paris 75013

France

jean.beuve@univ-paris1.fr

Marian W. Moszoro

International Monetary Fund

1900 Pennsylvania Ave NW

Washington, DC 20431

United States

and George Mason University

and SGH Warsaw School of Economics

mmoszoro@imf.org
Pablo T. Spiller

University of California, Berkeley

Walter A. Haas School of Business

Faculty Bldg. 593

Berkeley, CA 94720

and NBER

spiller@haas.berkeley.edu 


\section{Introduction}

Why are public contracts so often renegotiated? Guasch (2004) provides numerous examples of renegotiations in public-private agreements. By studying more than 1,000 public-private longterm contracts signed in Latin American countries between the mid-1980s and 2000, he found that 78 percent of transportation contracts and 92 percent of water and sewage contracts were renegotiated. Guasch's findings also show that renegotiations occur shortly after the award (on average, after 2.2 years) and often, at first glance, favor the private party.

Guasch (2004) suggests that renegotiations are a consequence of aggressive bidding. Because the government cannot credibly restrain from renegotiation and firms learn their type vis-à-vis competitors (i.e., cost structure, capabilities) after bidding, bid winning firms will be prone to renegotiate loss-bearing contracts (Laffont and Tirole 1993). Decarolis and Palumbo (2015) shows that design-and-build contracts - which are associated with less project specification detailing during the tender-reduce time-to-completion renegotiations, but increase price renegotiations. Coviello and Gagliarducci (2017) find that time-to-completion renegotiations increase with the mayor's tenure in office, which increases the likelihood of collusion between government officials and local bidders. Alternative explanations of frequent renegotiations point to government-led renegotiations (Guasch, Laffont, and Straub 2007) and renegotiations without hold-up that enable incumbent governments to circumvent budgetary rules before elections (Engel, Fischer, and Galetovic 2019).

Regardless of the framework mobilized to analyze public-private contracts, the high rate of renegotiation always comes as bad news and have raised doubts about the viability of the public-private partnership model in developing countries (Guasch, Laffont, and Straub 2008). High rates of renegotiation, however, are not specific to developing countries. Other studies have reported very high renegotiation rates in the United States (Engel, Fischer, and Galetovic 2011), the United Kingdom (NAO 2003), and France (Athias and Saussier 2007).

We challenge the industrial organization view on public contract renegotiation. As argued

by Spiller (2009, 2010), public contracts are characterized by intrinsic differences stemming from a substantial amount of supervision and control by political opponents and interest groups, who hold a stake in challenging and disrupting a contractual relationship. Consequently, unlike private contracting, a grasp on politics becomes paramount in understanding public contracting. 
Public contracts are awarded through a set of rule-based bureaucratic procedures. Rigid bureaucratic proceduralization imposes ex post stringent enforcement, intolerance to adaptation, and penalties for deviation. Moszoro and Spiller (2019) and Beuve, Moszoro, and Saussier (2019) showed that public contracts tend to be more rigid when public agents face tighter political competition and fear opportunistic challenges to their contractual decisions. From the public agent's perspective, contractual rigidity minimizes the risk of politically motivated challenges (Moszoro and Spiller 2012, 2014). From the contractor's perspective, contractual rigidity minimizes the risk of governmental opportunism, including unfair administrative treatment and creeping expropriation (Spiller 2013; Moszoro and Spiller 2014, 2016).

We conjecture that tight political competition, by increasing rigidity, leads to more frequent formal renegotiation of public contracts. When faced with unexpected circumstances, privateto-private contractees tend to adapt through informal adaptation. Because relational (informal) adaptations (Macaulay 1963) will normally lead to political (and potential judicial) challengesparticularly in jurisdictions of the type just described (Spiller 2009, 2010; Moszoro and Spiller 2019) - renegotiations of public contracts will tend to take the form of formal amendments. In other words, the political hazards - third-party and governmental opportunism - that induce higher rigidity in public contracts may also be conducive to more frequent formal renegotiations. The frequent renegotiation of public contracts, instead of being a sign of weakness (Guasch 2004), provides a "relational quality" (Spiller 2008; Spiller 2013) and indicates that the contractees are willing to adapt through time.

Previous studies on contract renegotiations (Bajari, McMillan, and Tadelis 2009; Bajari, Houghton, and Tadelis 2014, Crocker and Reynolds 1993; Hart and Moore 1988; Hart, Shleifer, and Vishny 1997; Hart 2003; Saussier 2000) have stressed complete versus incomplete contracting, where a complete contract precisely describes all possible states of the world and the expected outcomes and an incomplete contract vaguely describes the possible states of the world and expected outcomes. In contrast, we focus on the rigidity versus flexibility dimension of contracts - i.e., a flexible contract leaves room for possible deviation and ex-post adaptation, whereas a rigid contract does not - under political scrutiny. As a result, contractual rigidity and completeness (analogously, contractual flexibility and incompleteness) covary but do not equate (e.g., a contract may foresee all states of the world and still leave the parties to flexibly agree on the expected outcomes once the states of the world materialize). 
In this paper, (a) we model the public agent's choice whether to informally adapt through contractual flexibility or renegotiate in politically contestable jurisdictions and - accordingly(b) we revisit the empirical evidence on public contract renegotiations. Our study contributes to the public contracting literature by advancing a novel set of hypotheses based on political hazards specific to public procurers. The results are indicative that previous empirical studies pointing to the inefficiencies of public contracts related to high renegotiation rates may have overlooked part of the story. In fact, such inefficiencies may not be remediable (Williamson 1999), as the frequent renegotiations observed in public contracts can be understood as a consequence of their specific rigid nature instead of a manifestation of governmental opportunism or government incapacity to avoid renegotiation when dealing with opportunistic private corporations.

\section{Contract Flexibility and Political Tolerance}

Let $\mathbb{X}^{C} \subseteq \mathbf{R}_{+}$be the set of contractual terms at $t_{0}$ (e.g., cost, quality, attributes, and delivery time) and $\mathbb{S} \subseteq \mathbf{R}_{+}$be the set of possible states of the world upon contract delivery at $t_{1}$. The reference point $\bar{s}$ is the first-best contract in the absence of uncertainty. Without loss of generality, let $\mathbb{X}^{C}=\left[0, x^{C}\right]$ and $\mathbb{S}=[0, s]$, where $x^{C}$ and $s$ are the measures of the sets. Complete contracting - i.e., a contract with contingency clauses mapping all possible states of the world - is not possible due to the contractees' boundary rationality, thus $\mathbb{X}^{C} \subset \mathbb{S}$.

Let us further define contractual flexibility $\mathbb{X}^{F}=\left[0, x^{F}\right]=\left[0, \phi x^{C}\right]$ as the tolerance deviation from $\mathbb{X}^{C}$, where $\phi>1$ is a constant denoting flexibility $!^{1}$ Contract renegotiation is costly for the public agent. As long as the realized state of the world $s_{i} \subset \mathbb{S}$ is contained within the vicinity of the reference point of the contract, the status quo remains valid (i.e., contract continuation, with eventual informal adaptations). Technical contract renegotiation $(\nu=0)$ happens when the realized state of the world $s$ is outside the contractual terms and tolerated deviations, i.e.:

$$
\nu=\left\{\begin{array}{lll}
1 & \text { if } s \in \mathbb{X}^{F} & \text { (contract continuation) } \\
0 & \text { if } s \notin \mathbb{X}^{F} & \text { (contract renegotiation) }
\end{array}\right.
$$

Contractual flexibility accommodates contingencies not contained explicitly in the contract, and allows to avoid costly renegotiation. Moreover, when renegotiations do not conclude satisfactorily for both sides, the contract is terminated and tendered anew at a high cost. Contractual

\footnotetext{
${ }^{1}$ E.g., $\phi=1.2$ means that there is 20 percent technical deviation tolerance before the contract is renegotiated.
} 
flexibility, thus, preserves the contractual relationship as long as it is beneficial for the parties (Macaulay 1963).

Contractual flexibility, however, makes public contracts susceptible to (the whiff of) corruption. Neither the voters (i.e., the super-principal who gives the mandate to the public agent) nor the political opponents have perfect information about the public agent's actions and motivations. The information asymmetry regarding the public agent's actions is conducive to probity challenges from political opponents - sometimes in good faith, but often opportunistically. In anticipation, the public agent will deliberately self-constrain her contractual flexibility and adopt rigid procedures to reduce the information asymmetry between her perceived and actual actions and to prove probity (Moszoro and Spiller 2019), even when it is not her intent to so behave.

Let $\mathbb{X}^{P}=\left[0, x^{P}\right]$ be the political tolerance for deviations from the contractual reference point $\bar{s}$. Political tolerance is given by the cultural setup (including trust in institutions), the rule of law, and foremost political contestability: high political competition correlates with low political tolerance, as political opponents will take advantage to overturn the incumbent public agent. If the realized state of the world $s$ is outside the political tolerance $\mathbb{X}^{P}$, the incumbent public agent is replaced $(\lambda=0)$, i.e.:

$$
\lambda=\left\{\begin{array}{lll}
1 & \text { if } s \in \mathbb{X}^{P} & \text { (public agent continuation) } \\
0 & \text { if } s \notin \mathbb{X}^{P} & \text { (public agent turnover) }
\end{array}\right.
$$

with $\nu \geq \lambda$ : i.e., if the public agent's turnover is due to a politically-motivated challenge to the contract, that contract will likely be renegotiated by the challenger once she is in office.

Uncertainty over the states of the world $\mathbb{S}$ may result in technically-triggered renegotiations $(\nu=0)$ if contractual flexibility $\mathbb{X}^{F}$ is low. Likewise, political opportunism may lead to politically-triggered renegotiations $(\lambda=0)$ if political tolerance $\mathbb{X}^{P}$ is low, e.g., in politically contestable jurisdictions where political scrutiny and competition is salient.

We advance the following propositions:2

Proposition 1 The probability of contract continuation rises in the set of contractual terms: i.e., $\partial \mathbb{E}(\operatorname{Pr}[\nu=1]) / \partial x^{C}>0$.

Proposition 2 The probability of contract continuation rises in contractual flexibility: i.e., $\partial \mathbb{E}(\operatorname{Pr}[\nu=1]) / \partial x^{F}>0$.

\footnotetext{
${ }^{2}$ See Appendix A for the proofs.
} 
Proposition 3 The probability of a politician's continuation in office rises in contractual rigidity: i.e., $\partial \mathbb{E}(\operatorname{Pr}[\lambda=1]) / \partial x^{C}<0$.

Proposition 4 The probability of a politician's continuation in office rises in political tolerance: i.e., $\partial \mathbb{E}(\operatorname{Pr}[\lambda=1]) / \partial x^{P}>0$.

A manager benefits from office tenure and contract continuation. Calling $O$ the benefits from office tenure and $Q$ the benefits from contract performance $3^{3}$ and assuming that the manager's utility is linear in both terms - i.e., without loss of generality, she cares equally about both terms - she will maximize her expected utility $U$ by strategically choosing contractual terms $\mathbb{X}^{C}$. Formally:

$$
\max _{x^{C}} \mathbb{E}(U)=u[\mathbb{E}(\lambda) O+\mathbb{E}(\lambda) \mathbb{E}(\nu) Q]-C\left(x^{C}\right)
$$

where $C$ is the contracting cost which rises in the set of contractual terms (i.e., $\partial C / \partial x^{C}>0$ ).

Figure 1 depicts a graphical representation of the contractual space $\mathbf{R}_{+}^{2}$. The left graph shows a contractual environment with large political tolerance (e.g., private-to-private contracting). Realized state of the world $s_{1,2,3}$ at $t_{1}$ are within $\mathbb{X}^{C}$, thus contractually safe; $s_{4}$ is outside the contractual space but within the contractual tolerance $\mathbb{X}^{F}$. If state $s_{5}$ is realized, albeit politically tolerable, the contract will be subject to renegotiation.

The right graph shows a contractual environment with political scrutiny (e.g., public-toprivate contracts). As political tolerance $\mathbb{X}^{P}$ shrinks, managers will prefer more rigid contracts, decreasing the contractual $\mathbb{X}^{C}$ and flexibility $\mathbb{X}^{F}$ spaces, and increasing the states of the world subject to renegotiation. If the realized state of the world at $t_{1}$ is $s_{1} \subset \mathbb{X}^{P}$, the contract is technically and politically safe $(\nu, \lambda=1)$, and will continue. If $s_{2}$ is realized, the contract is within the technical contractual terms $(\nu=1)$, but politically contestable $(\lambda=0)$, and the incumbent policymaker may be under political pressure to renegotiate the contract. If $s_{3}$ is realized, the contract is still technically viable (the contractor is willing to adapt, $\nu=1$ ), but politically contestable $(\lambda=0)$ : the incumbent policymaker will be under political pressure to renegotiate the contract. If $s_{4}$ or $s_{5}$ is realized, the contract is technically and politically unviable $(\nu, \lambda=0)$ and will be renegotiated.

\footnotetext{
${ }^{3}$ In management parlance, $O$ are the extrinsic incentives from office tenure, including perquisites and corruption rents (Kwon 2014; Liu and Tang 2011; Wright 2007) and $Q$ are the intrinsic incentives from contract continuation, e.g., stable and reliable service for the constituencies (Dur and Zoutenbier 2015 Friebel, Kosfeld, and Thielmann 2019).
} 
Contractual flexibility $\phi$ and political tolerance $\mathbb{X}^{P}$ are exogenous to the contractual parties (i.e., long-term path dependent). The parties negotiate over $\mathbb{X}^{C}$. The set of contractual terms increases as $\mathbb{X}^{C}$ expands, thus lowering the likelihood of technical renegotiation as more states of the world are contemplated in the contract. On the other hand, contract rigidity increases as $\mathbb{X}^{C}$ shrinks towards the reference point, lowering the likelihood of political challenges.

Figure 1: This figure presents a two-dimensional contractual space $\mathbf{R}_{+}^{2} \cdot \mathbb{S}$ is the set of all possible states of the world upon contract delivery at $t_{1}$ and $s_{1,2, \ldots}$ are examples of realizations of states of the world at $t_{1} \cdot \mathbb{X}^{C}$ (grey and red areas) is the set of contractual terms at $t_{0}$ (e.g., cost, quality, attributes, and delivery time). $\mathbb{X}^{F}$ (green area) is the contractual flexibility, i.e., the tolerance deviation from $\mathbb{X}^{C} \cdot \mathbb{X}^{P}$ (red area) is the political tolerance for deviations from the contractual reference point. $\mathbb{X}^{F}$ and $\mathbb{X}^{P}$ are exogenous, and the parties negotiate over $\mathbb{X}^{C}$. The set of contractual terms increases as $\mathbb{X}^{C}$ expands (green solid arrow). Contract rigidity increases as $\mathbb{X}^{C}$ shrinks towards the reference point (red dotted arrow). The left graph shows a contractual environment with large political tolerance (e.g., private-to-private contracting). The right graph shows a contractual environment with political scrutiny (e.g., public-to-private contracts).
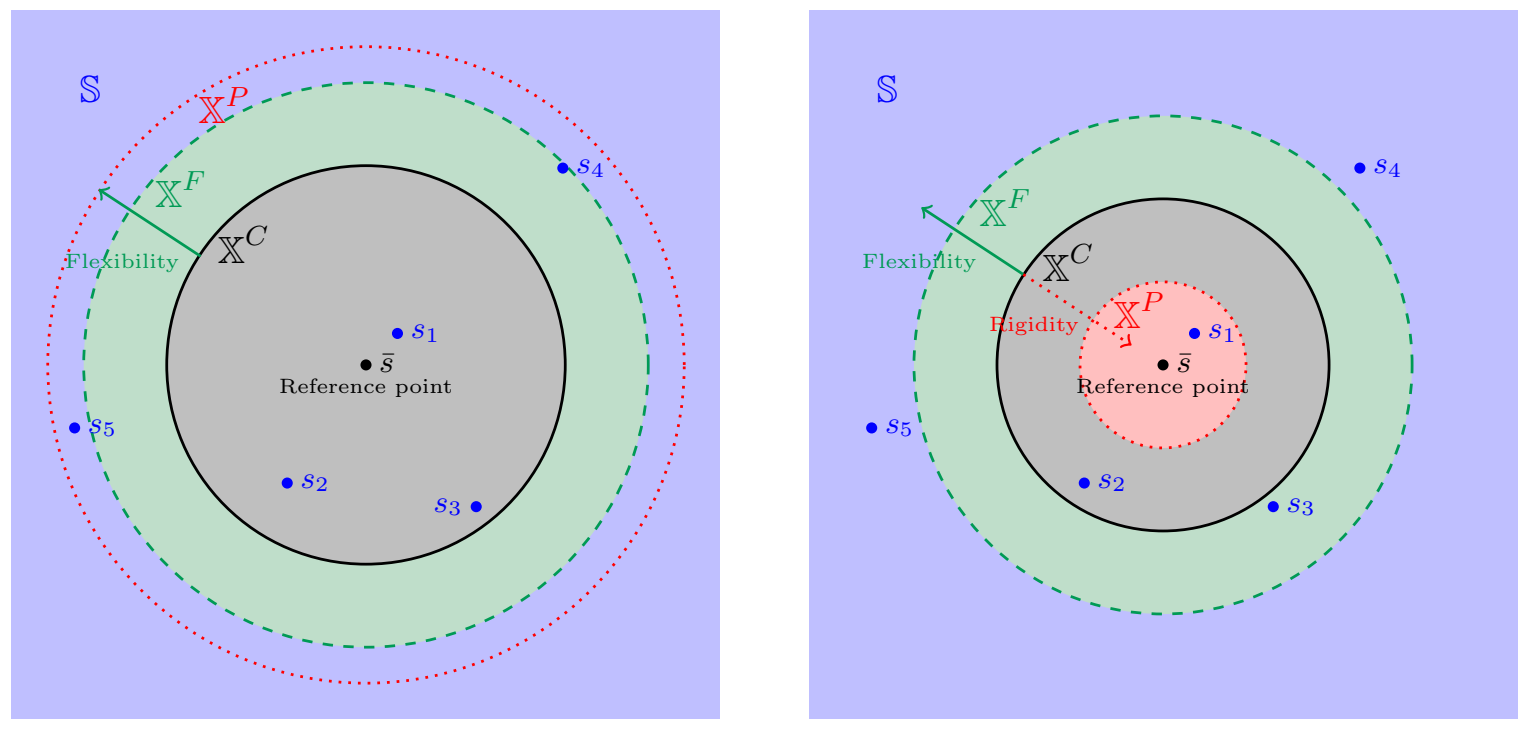

This simple framework yields two testable hypotheses. Political scrutiny is irrelevant for most private-to-private contracts (i.e., in private-to-private setups $\mathbb{X}^{P}$ is large or nonapplicable). Conversely, public agents will trade the set of contractual terms for contractual rigidity (i.e., lower $\mathbb{X}^{C}$ ) to keep political challenges at bay. From Propositions 2 and 3 , therefore:

Hypothesis 1 For comparable goods, public-to-private contracts are formally renegotiated more often than private-to-private contracts.

Political contestability increases third-party opportunistic challenges (Moszoro and Spiller 2019 ), thus decreases political tolerance $\mathbb{X}^{P}$. Managers respond to lower political tolerance with 
higher rigidity. Consequently, from Propositions 1 and 4

Hypothesis 2 Political contestability leads to higher renegotiation rates in public-to-private contracts, while it has no impact on private-to-private contracts.

\section{Data}

We focus on the car park sector in France which is particularly suitable for our purposes. First, parking management is a standard service with verifiable quality. Second, France displays a homogenized legal and administrative regime at the subnational level. Thus, car park contracts in France are comparable across providers and contracting administrations.

\subsection{Sector Characteristics}

Throughout the world, cities are normally tasked with providing on-street and off-street parking spaces. The positive externalities and social benefits (e.g., intermodality and urban development) derived from high-quality construction and efficient parking management as well as the negative externalities resulting from increased traffic volumes justify their remittance to local authorities. While the public authorities are legally obliged to retain ownership of parking spaces, they can outsource the provision of infrastructure and services through public-private arrangements.

In France, outsourcing the construction and management of parking lots to private operators is widespread. According to the French Ministry of Sustainable Development, in 2019 about 72 percent of parking lots were organized through outsourced management and 28 percent were provided in-house through public provision.

The French car park sector is characterized by a growing level of competitive pressure between French firms (local operators as well as larger companies) and, more recently, between national and foreign operators (ANFA 2019) A Additionally, the competitive pressure also comes from the threat of municipalization when contracts end (i.e., contracting parties are not locked in through specific investments at the contract renewal). The absence of bilateral dependency between municipalities and operators is possible because parking management is a standard product. According to a survey of public managers' perceptions, parking lots appear among the

\footnotetext{
${ }^{4}$ Indigo (formerly Vinci Park), Q-Park, Epolia, Efia, Interparking, Parking de France, UrbisPark, AutoCité, and SAGS are the most frequent bidders in France.
} 
least asset-specific activities in the public management domain (Brown and Potoski 2003) $5^{5}$

On the other hand, recent studies on public procurement highlight that parking services are associated with a medium level of resident sensitivity and the price of public parking is one of the front-page topics before local elections in France (Beuve and Le Squeren 2016). Consequently, the parking sector is susceptible to political interference. For example, in June 2015 the daily regional press reported that the city council majority in Saint-Etienne, France, raised prices by renegotiating underground parking contracts entrusted to private partners to comply with a new legislative framework - the "Hamon Law" on consumption adopted in March 18, 2014which required pricing for every 15 minutes to allow car drivers to pay amounts closer to their actual consumption. The new price schedule was then submitted to the vote of the city council. The motion was rejected by the opposition, which publicly blamed the city council majority for conducting negotiations as "surrogates." A political opponent of the mayor even declared that the contract was "either a gift or poorly negotiated." The city counsel majority replied by blaming the former mayor about the absence of contract enforcement in the past. 6

In sum, the car park sector is a suitable arena to investigate the impact of the political dimension of public contracts.

\subsection{Contract Characteristics}

Three main contractual arrangements encompass the parking sector in France: concession contracts, operating contracts, and provision-of-services contracts.

Concession Contracts are used for greenfield (new) and brownfield (renovated) parking developments. These are long-term contracts (30 years on average in our dataset), which provide sufficient time for private operators to invest and pay off debt. In such contracts, the operator bears the demand risk and collects user fees. In our dataset as well as in real life, concession contracts are utilized by municipalities and not by private procurers. We have only two concession contracts among the private contracts in our data, and hence we excluded concession contracts from our sample to avoid overidentification.

\footnotetext{
${ }^{5}$ For reference, the asset specificity associated with parking lots was $2.36 / 5$, whereas the asset specificity associated with urban transport and water sectors was equal to 3.35 and 3.94, respectively (Brown and Potoski 2003). Levin and Tadelis (2010) and Hefetz and Warner (2012) replicate similar levels of asset specificity for the US using the same type of survey.

6 See: Xavier Alix, "Parkings stéphanois: une renégociation plus ou moins bonne?", L'Essor, June 10, 2015. Available at: https://www.lessor42.fr/parkings-une-renegociation-plus-ou-moins-bonne-10303.html, accessed June 26, 2018.
} 
Operating Contracts are used when parking infrastructure is already built but requires a significant level of investment to renovate and maintain. These contracts are shorter in time than concession contracts (18.2 years on average in our dataset). The operator bears the demand risk and collects user fees. Operating contracts are also subject to the political, economic, social, and technological changes that may occur during execution of the contract.

Provision-of-Services Contracts manage existing on-street parking lots, which require no investments. These contracts are the shortest in time (3.2 years on average in our dataset).

\subsection{Contractual and Political Data}

The French car park sector is not regulated by a national authority and data is not centralized. To generate the dataset used in this study, we gathered all contracts signed by the leading company in the French car parking sector (42 percent of market share among private operators and 31 percent of total market share). The entire dataset is composed of almost 1,000 contracts signed between 1963 and 2008. This leading company has been in the market for a long time which helps our identification of public versus private contractees and partials out the confounding effects of contractual dynamics of newer companies with different corporate governance.

As mentioned earlier, we excluded concession contracts: focusing on operating and provisionof-services contracts allows for a fairer comparison among different levels of contract rigidity. Municipal election data are available since 1983, which further narrowed our sample. Finally, we also excluded observations from very small cities for which the elections data are not available and metropolitan areas - i.e., Paris, Lyon, and Marseille - where the electoral system is organized in administrative districts (i.e., arrondissements), thus precluding the univocal mapping of contractual and electoral data.

We ended with 279 contractual arrangements signed by the leading parking service provider across 58 departments (out of 96) in metropolitan France. The procurers include 132 public administrations and 24 private companies (clinics, shopping malls, airports).

The political data we gathered concern the outcomes of all municipal elections from 1983 through 2008.7 Elections are organized (in principle) every six years to elect the mayor and

\footnotetext{
7 Municipal elections in France were held in 1983, 1989, 1995, 2001, and 2008. The data were obtained through the Center for Socio-Political Data (CDSP).
} 
the members of the city council by a majority vote. If a majority vote is not achieved in the first round, a second round takes place. Each mayoral candidate presents a list of potential deputies (as many deputies as the number of seats on the city council). The list that obtains the most votes obtains 50 percent of the seats on the city council. The remaining seats are distributed among all lists of potential deputies (including the majority list) which received at least 5 percent of the votes cast.

The city council, chaired by the mayor, collectively has the legislative authority to manage the affairs of the municipality through its decisions. Her scope of authority spans from approving budgets, determining local tax rates, creating or canceling communal jobs, acquiring and disposing of communal property, approving loans, grants, and subsidies, to setting tariffs for communal services and on-street parking.

\section{Empirical Strategy}

Our sample presents the ideal characteristics to test our hypotheses, as there is only one contractor and parking represents a standard product. Therefore, a large part of the heterogeneity in our dataset comes from the procurer's organizational type (public versus private), as well as the cross-sectional and time-varying political contestability in the public administrations.

\subsection{Dependent Variables}

Renegotiation refers both to the process and outcome that changes the original agreed contractual terms. Long-term contracts generally define ex ante the triggers, scope, and manner in which eventual changes to agreed terms take place. In this study, we do not report the renegotiation terms embedded in original contracts, nor the talks the contractees held after the contract was signed.

Instead, we focus on the ex post outcomes of renegotiations formalized in written amendments to the original contracts. Specifically, we define the frequency of formal renegotiations as the sum of amendments of a particular contract divided by its length in years (if expired) or the

time elapsed since closing the contract (if still active) in years, which yields average number of formal renegotiations per year per contract. 


\subsection{Public versus Private Contracts}

Moszoro, Spiller, and Stolorz (2016) showed that political contestability leads to rigidity and also to more renegotiations using contracts filled through the SEC's Edgar system. They studied contracts in regulated versus non-regulated industries, both in the private-sector domain, thus blurring their measure of "publicness." In the dataset used in this paper, the public-sector versus private-sector domains are clearly identified.

To ensure that we correctly classified public versus private contracts, we hand-coded a dummy variable public that equals one when the contract is signed between a private contractor and a public administration, and zero when the contract is signed between a private contractor and a private procurer. Consequently, a private contract does not involve elected officials, and public accountability is delimited by the standard regulations of the industry.

Public-private and private-private contracts may differ along many unobserved dimensions, including: the nature of services, location, type and history of clients, pricing schemes, subsidies, etc. Our methodology addresses these concerns. First, comparability is validated by the fact that parking agreements correspond to a standard product (cf. section 3.1). It is similar to manage a car park for a public hospital and a private clinic, or to manage private and public car parks located near airports. Moreover, parking lots located close to shopping centers are alternately managed through public and private contracts. Second, our sample is relatively well distributed geographically, covering half of the French departments (see Figure 2). Lastly, given the competitiveness of the industry the assignment of the procurer's type - public or private - is random: i.e., from the contractor's perspective the arrival of contracts from public or private procurers is independent from the contractor.

\subsection{Contract Rigidity}

To assess the rigidity levels of our contracts we follow Moszoro, Spiller, and Stolorz (2016) and construct "dictionaries" by which we machine-read rigidity categories: arbitration, certification, evaluation, litigation, penalties, termination, and contingencies.

The rigidity categories capture relevant contractual clauses intended to signal probity and lower the likelihood of challenges by third parties. Table 1 presents the list of search terms 
Figure 2: This figure presents the number of public and private contracts by department in our sample. The left graph plots pie charts for all France. The right graph zooms in Île-de-France, the most populous French region located in the North-center and often called région parisienne ("Paris region") because of its proximity to the city of Paris. The red color in the pie charts correspond to public contracts, the blue color corresponds to private contracts, and the size of the pie corresponds to the number of contracts by department in our sample.
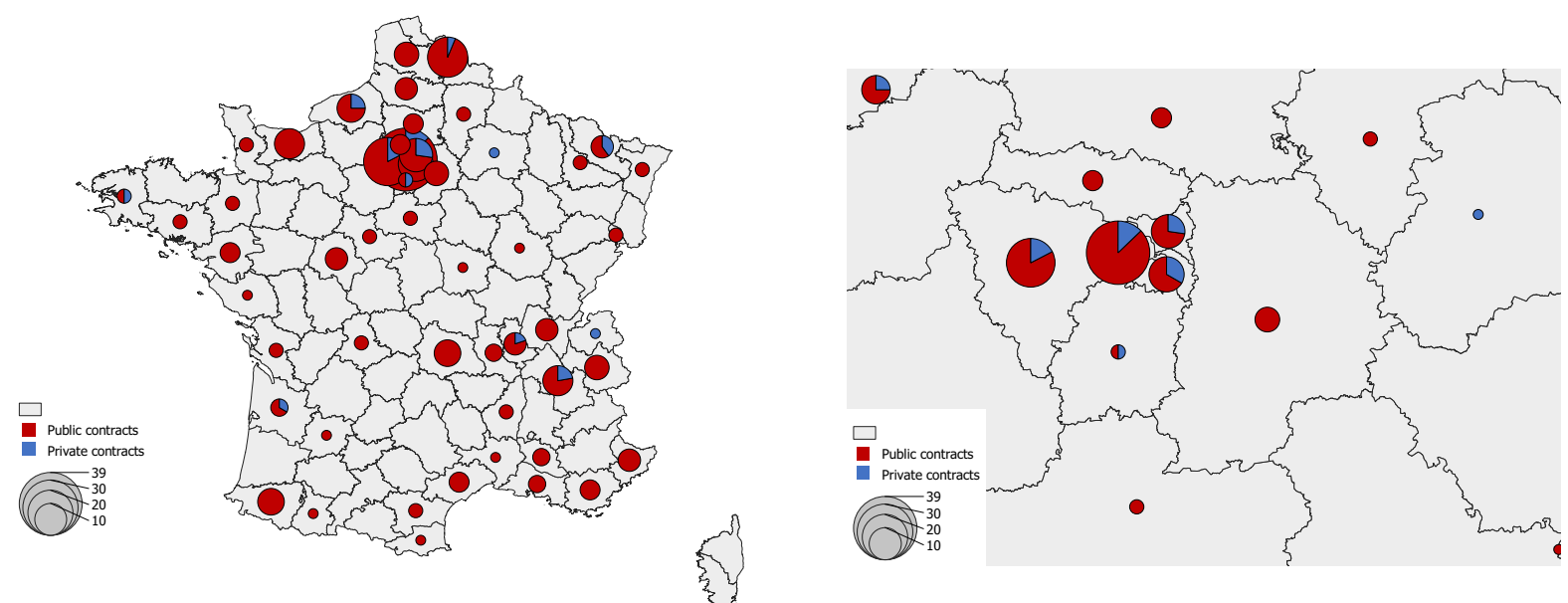

clustered into seven rigidity categorie: 8 and their total count.

These terms univocally relate to their corresponding categories. Arbitration clauses submit plausible disputes to an arbitrator instead of a court 9 Certification clauses regulate the contractor regarding certification requirements. Evaluation clauses introduce duties regarding delivery. Litigation clauses appear as triggers to a lawsuit. Penalty clauses describe the damages and sanctions for contract breaching. Termination clauses signal ways to resolve intractable contract disruption. Finally, contingency clauses make provisions for future possible, but uncertain events and circumstances. We created as many variables as rigidity dimensions.

Then, we used the normalized frequencies (i.e., $z$-values) of the total count of search terms in each category to measure the degree of difference between contracts. For example, we trans-

\footnotetext{
${ }^{8}$ We machine-read "stemmed" words, i.e., plurals (e.g., penalties) and variations (e.g., penalized) are also included.

${ }^{9}$ Contracts submitting to arbitration have more details because there will be fewer deposition opportunities. Public contracts may have more arbitration clauses to minimize the risks of (unfavorable) court decisions. Public managers may also prefer arbitration because it is faster and more confidential than litigation, so they are less exposed to third parties.

${ }^{10}$ See Schwartz and Watson (2012) for an explanation of the appropriateness of "whereas" as an arbitration keyword.
} 
Table 1: This table presents the search terms grouped into rigidity categories.

\begin{tabular}{|c|c|c|}
\hline Arbitration & $\begin{array}{l}\text { appeal, arbitration, conciliation, guarantee, intervention, mediation, set- } \\
\text { tlement, warranty, whereas }{ }^{10}\end{array}$ & 10,241 \\
\hline Certification & certification, permit, regulation & 3,263 \\
\hline Evaluation & $\begin{array}{l}\text { accountability, control, covenant, obligation, quality, specification, } \\
\text { scrutiny }\end{array}$ & 8,090 \\
\hline Litigation & $\begin{array}{l}\text { court, dispute, indictment, jury, lawsuit, litigation, pleading, prosecu- } \\
\text { tion, trial }\end{array}$ & 2,479 \\
\hline Penalties & damage, fine, indemnification, penalty, sanction & 5,431 \\
\hline Termination & breach, cancel, dissolution, separation, termination, unilateral & 580 \\
\hline Contingencies & $\begin{array}{l}\text { contingent, if, provided that, providing that, subject to, whenever, } \\
\text { whether }\end{array}$ & 4,488 \\
\hline Total & & 34,572 \\
\hline
\end{tabular}

formed the total word count of search terms in the Arbitration category by calculating:

$$
z \text { Arbitration }=\frac{\text { Arbitration }-\mu}{\sigma}
$$

where $\mu$ is the mean and $\sigma$ is the standard deviation of the count of Arbitration search terms across all contracts. This gives us a global rigidity measure, zRigidity:

$$
\begin{array}{r}
z \text { Rigidity }=z \text { Arbitration }+z \text { Certification }+z \text { Evaluation }+z \text { Litigation } \\
+z \text { Penalties }+z \text { Termination }+z \text { Contingencies }
\end{array}
$$

\subsection{Political Contestability}

In their seminal contributions about the effect of political competition on policy in US states, Besley and Case (2003) and Besley, Persson, and Sturm (2010) measure the distance fraction of seats held by one party to 0.5 . This measure fits well in bipartisan political setups. In France, political fragmentation is usually higher: even if two parties can be legitimately defined as dominant (i.e., the left-wing party Parti Socialiste and the right-wing parties Les Républicains) ${ }^{11}$ other political forces - extremist, centrist, and green parties - play an important role and it is common to have city mayors who belong to one of these not-dominant parties. Consequently, we adopt different measures of political competition to capture party fragmentation.

\footnotetext{
11 The name of the actual party Les Républicains had changed many times during the period under study: Rassemblement Pour la République, Union Pour la Majorité Présidentielle, Les Républicains.
} 
Following Laakso and Taagepera (1979), Ferraz and Finan (2011), and Berliner and Erlich (2015), we base our measure on the Herfindhal-Hirschman Index (HHI) and effective number of parties. The Number of Effective Parties $(N E P)$ is defined as the inverse of the sum of squared vote shares for each party $(H H I)$ :

$$
\begin{gathered}
H H I_{m, t}=\sum_{i=0}^{n} P_{i, m, t}{ }^{2} \\
N E P_{m, t}=\frac{1}{H H I_{m, t}}
\end{gathered}
$$

where $P_{i, m, t}$ is the vote share of each party $i$ in municipality $m$ at time $t$ during the first round of municipal elections preceding the date of signature. NEP lower than two corresponds to a single-party domination, while increasing values beyond that reflect the extent to which effective competition is between two or more than two parties. $N E P$ is an intuitive measure of political concentration and displays a normal distribution, whereas $H H I$ is right-skewed. According to our Hypothesis 1, we expect politically competitive municipalities to utilize more rigid contracts and renegotiate them at a higher rate.

The NEP index does not take into account that the party with the highest vote share in the first round may not win of the election in the second round. Moreover, political contestability could be higher in the case of a dominant party but multiple political contenders, facilitating scrutiny and hampering collusion. To address this issue, we define a second variable to capture the opposition's strength. We exclude the winning party $W P_{m, t}$ and look at the concentration of all non-winning parties $N W P_{j, m, t}$, where $j$ stands for all the non-winning parties during the first round of elections. Analogously to NEP, the variable Number of Residual Effective Parties $(N R E P)$ is defined as the inverse of Residual_HHI $I_{m, t}$ in municipality $m$ at time $t$ and allows to measure the strength of political opposition:

$$
\begin{gathered}
\text { Residual_HHI } I_{m, t}=\frac{\sum_{j=0}^{n} N W P_{j, m, t}^{2}}{\left(1-W P_{m, t}\right)^{2}} \\
N R E P_{m, t}=\frac{1}{\text { Residual_HHI } H, t}
\end{gathered}
$$

\subsection{Control Variables}

We include a set of control variables that can affect contractual rigidity. First, we take into account two different contract types described in section 3.2 . Operating ${ }_{i, t}$, and Provision_of-- 
Services $_{i, t}$. In the estimations, provision-of-services contracts are compared to operating contracts through a dummy variable. Because these contractual arrangements correspond to different levels of investment and complexity, we should observe that provision-of-services less rigid than operating contracts .

Second, contractual requirements can also vary among the same contract types. We take into account the number of parking places $\left(\right.$ Places $\left._{i, t}\right)$ and the type of service (On-street $t_{i, t}$, Underground $_{i, t}$, or Both_Services $\left.i, t\right)$ managed by the contract. The type of service is orthogonal to the contract types - provision-of-services and operating contracts - thus these variables add to the strength of our analysis.

Third, we control for the possible influence of a corrupted environment on public contracts. The sizable financial flows involved make public procurement particularly susceptible to fraud and corruption. Our variable Corruption - obtained from Transparency International Francemeasures the number of cases of corruption implicating the mayor or a member of the municipal council in the three years preceding the date the contract was signed. This measure is conditional on corruption cases being detected and prosecuted, which does not necessarily reflect endemic corruption.

Fourth, we control for the city's size (measured by the natural logarithm of the number of inhabitants, Inhabitants $s_{i, t}$ ) and the political leaning of the city's mayor (Left_Wing L $_{i, t}$ or Right_Wing $_{i, t}$ ) where the parking lot was located.

Fifth, we introduce several variables to control for path dependency arising from cumulative

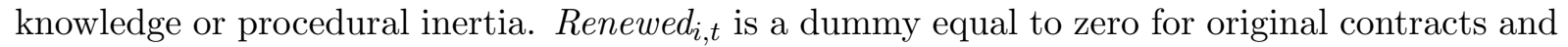

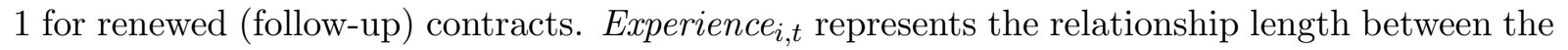
contractees in years (i.e., the difference between the dates that the contract was signed and their first bilateral contract). Finally, Past_Contracts $s_{i, t}$ captures the number of all common contracts up to the observation date.

Sixth, since the estimation results may be driven by unobserved characteristics of the sector, which may had evolved over such a long period (24 years), we control for potential biases by introducing year fixed effects corresponding to the year in which the contract was signed 12

\footnotetext{
${ }^{12}$ Contracts tend to become more rigid over time, which may be indicative of a learning process and "red tape" inertia by public administrations, where subsequent arrangements replicate the contractual clauses of previous contracts and add new ones. In unreported regressions, we use a time trend to see whether this learning process (i.e., cumulative rigidity) from public administrations could affect our estimates. The results remained
} 
Finally, we cluster our estimations at departmental level (58 jurisdictions). Descriptive statistics of the variables used in the empirical tests are provided in Table 2.

\section{Identification}

Moszoro and Spiller (2019) argue that the specific nature of public contracts lead them to a higher level of rigidity than private contracts. Due to third-party opportunism that pushes for rigid contracts at their initial stage, the same political hazards should also make public contracts be more formally renegotiated: since relational contracting is not an option in for public contracts in highly contested political environments, each renegotiation should be traduced into a formal amendment. As a consequence, we should observe two trends: on the one hand, public contracts are more renegotiated than private contracts; on the other hand, public contracts are more renegotiated in environments of political contestability.

At first glance, figure 3 confirms that the frequency of renegotiations is higher for public contracts than for private contracts.

Figure 3: This figure presents the frequency of renegotiations defined as the number of formal amendments to a contract divided by the time elapsed since its signing. Public are contracts signed between a municipality and a contractor; private are contracts signed between a private-sector procurer and a contractor.

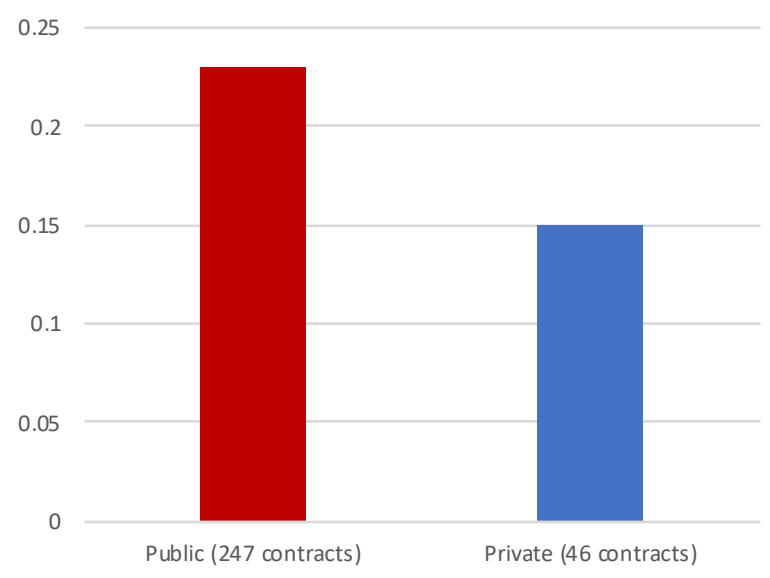

To test Hypothesis 1, we estimate a linear OLS model:

$$
\text { Frequency of renegotiations }_{i, t}=\alpha+\beta_{1} \text { Public }_{i, t}+\gamma Y_{i, t}+\epsilon_{i, t}
$$

where Frequency of renegotiations $s_{i, t}$ is the number of amendments divided by the duration of

qualitatively the same. 
the contract $i, P u b l i c_{i, t}$ is the dummy variable indicating whether contract $i$ signed at date $t$ is a public contract, and $Y$ is a vector of control variables and $\epsilon_{i, t}$ is the error term.

Next, we test Hypothesis 2 using a 2SLS system of equations:

$$
\left\{\begin{array}{l}
\text { Frequency of renegotiations } s_{i, t}=\beta_{0}+\beta_{1} \text { Contractual Rigidity } y_{i, t}+\gamma_{j} Y_{i, t}+\epsilon_{i, t} \\
\text { Contractual rigidity }{ }_{i, t}=\beta_{2}+\beta_{3} \text { Public }_{i, t} \times \text { Political Contestability } y_{i, t}+\gamma_{k} Y_{i, t}+\zeta_{i, t}
\end{array}\right.
$$

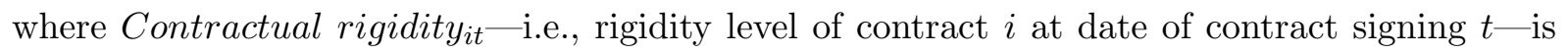
instrumented using measures of political contestability described in section 4.4 .

\section{$6 \quad$ Results}

To test Hypothesis 1 on whether public contracts are renegotiated more often than private contracts, we regress the frequency of contract renegotiations on a dummy variable equal to 1 for public contracts and zero for private contracts. Table 3 presents the results of OLS regressions estimating equation (10). On average, public-to-private contracts are renegotiated 7-13 percent more often than private-to-private contracts.

The results are economically and statistically significant and robust to the inclusion of covariates and controls (see models 2-3). Unsurprisingly, renewed (follow-up) contracts are renegotiated less often than original contracts since renewed contracts may have already been renegotiated at renewal time. Interestingly, contracts for larger parking lots measured by number of places are renegotiated less frequently than contracts for smaller parking lots (see model 2); this relationship, however, vanishes when adding further controls (see model 3).

To test Hypothesis 2 on whether the frequency of public contract renegotiations rises with political contestability through contractual rigidity, we instrument contractual rigidity with measures of public scrutiny and political competition. Beuve, Moszoro, and Saussier (2019) showed that political contestability causes public (but not private) contractual rigidity. Thus, political contestability is a suitable instrument for contractual rigidity, since contractual rigidity cannot cause a contract to become public or increase the number of parties in an electoral race (i.e., the exclusion restriction holds).

Table 4 presents the results of 2SLS estimations of equation (11). The first stage estimates contractual rigidity with a dummy variable equal to 1 for contracts in the public domain (model 1), the number of equal parties in a municipal election race defined as the inverse of the sum of squared vote shares for each party (model 2), and the number of equal opposition 
parties in a municipal election race defined as the inverse of the sum of squared vote shares for each opposition party, i.e., without the winning party vote share (model 3). The first-stage estimations show that political contestability is correlated with contractual rigidity for public contracts.

Further, second-stage regressions show that the frequency of renegotiations increase with contractual rigidity. Our contractual rigidity measure is the sum of seven $z$-scores. Thus, the point estimates show that an increase in one standard deviation in each category of contractual rigidity increases contract renegotiation by $7.7-10.5$ percent, a substantial increase from an unconditional average of 22 percent. In sum, public contracts are renegotiated more often because their level of rigidity is much higher. The reason why few private contracts get renegotiated is because their average rigidity is low (as compared to public contracts), and only those contracts which are rigid get renegotiated.

\section{Discussion and Conclusions}

We advance a theoretical framework for a novel set of hypotheses regarding the high rate of public contract renegotiation based on third-party political hazards. We find evidence that public contracts are renegotiated 7-13 percent more frequently than comparable private contracts due to their higher procedural rigidity, which is a way by which public agents minimize the risks of opportunistic challenges from political competitors.

The model also captures relevant features beyond the scope of our data for further research:

(a) Technology shocks and severe economic crises move the contractual reference point, thus will likely induce renegotiations. During the time span of our sample, the car park sector was not subject to major supply- or demand-side shocks. The advancement of electro-mobility may trigger renegotiations of car park contracts (e.g., to include electric chargers). Likewise, extended lockdown periods during the COVID-19 pandemic - when car parks remained largely idle - can foster price and land use renegotiations.

(b) Corruption implicates a certain degree of collusion among the political establishment and higher tolerance among political opponents, consequently lower contractual rigidity. On the other hand, corruption increases graspable rents from tenure $O$ and may trigger governmentinitiated opportunistic renegotiations described by Guasch, Laffont, and Straub (2007). This is not a concern for our identification, however, as corruption in France does not seem to 
affect contractual features in the car park sector (Beuve, Moszoro, and Saussier 2019).

The results suggest that previous empirical studies pointing to the inefficiencies of public contracts related to high renegotiation rates are flawed. Frequent renegotiations observed in public contracts can be understood in part as a consequence of their non-remediable rigid nature instead of a manifestation of opportunistic behavior whether by bidders or public agents. 


\section{References}

ANFA (2019). Autofocus. Les études de l'observatoire de l'ANFA 76, Association Nationale pour la Formation Automobile.

Athias, L. and S. Saussier (2007). Un partenariat public-privé rigide ou flexible? Théorie et applications aux concessions routieres. Revue Economique 58(3), 565-576.

Bajari, P., S. Houghton, and S. Tadelis (2014). Bidding for incomplete contracts: An empirical analysis of adaptation costs. American Economic Review 104(4), 1288-1319.

Bajari, P., R. McMillan, and S. Tadelis (2009). Auctions versus negotiations in procurement: An empirical analysis. Journal of Law, Economics, E Organization 25(2), 372-399.

Berliner, D. and A. Erlich (2015). Competing for transparency: Political competition and institutional reform in Mexican states. American Political Science Review 109(1), 110128.

Besley, T. and A. Case (2003). Political institutions and policy choices: Evidence from the United States. Journal of Economic Literature 41(1), 7-73.

Besley, T., T. Persson, and D. M. Sturm (2010). Political competition, policy and growth: Theory and evidence from the US. Review of Economic Studies 77(4), 1329-1352.

Beuve, J. and Z. Le Squeren (2016). When does ideology matter? An empirical analysis of French municipalities' make-or-buy choices. Chair EPPP working paper.

Beuve, J., M. W. Moszoro, and S. Saussier (2019). Political contestability and public contract rigidity: An analysis of procurement contracts. Journal of Economics \& Management Strategy 28(2), 316-335.

Brown, T. L. and M. Potoski (2003). Managing contract performance: A transaction costs approach. Journal of Policy Analysis \& Management 22, 275-297.

Coviello, D. and S. Gagliarducci (2017). Tenure in office and public procurement. American Economic Journal: Economic Policy 9(3), 59-105.

Crocker, K. J. and K. J. Reynolds (1993). The efficiency of incomplete contracts: An empirical analysis of Air Force engine procurement. RAND Journal of Economics 24(1), 126-146.

Decarolis, F. and G. Palumbo (2015). Renegotiation of public contracts: An empirical analysis. Economics Letters 132, 77-81. 
Dur, R. and R. Zoutenbier (2015). Intrinsic motivations of public sector employees: Evidence for germany. German Economic Review 16(3), 343-366.

Engel, E., R. Fischer, and A. Galetovic (2011). Public-private partnerships to revamp U.S. infrastructure. The Hamilton Project - Brookings, 1-26.

Engel, E., R. Fischer, and A. Galetovic (2019). Soft budgets and endogenous renegotiations in transport PPPs: An equilibrium analysis. Economics of Transportation 17, 40-50.

Ferraz, C. and F. Finan (2011). Electoral accountability and corruption: Evidence from the audits of local governments. American Economic Review 101(4), 1274-1311.

Friebel, G., M. Kosfeld, and G. Thielmann (2019). Trust the police? self-selection of motivated agents into the german police force. American Economic Journal: Microeconomics 11(4), $59-78$.

Guasch, J. L. (2004). Granting and Renegotiating Infrastructure Concessions: Doing it Right. Washington, DC: World Bank Publications.

Guasch, J. L., J.-J. Laffont, and S. Straub (2007). Concessions of infrastructure in Latin America: Government-led renegotiations. Journal of Applied Econometrics 22(7), 12671294.

Guasch, J.-L., J.-J. Laffont, and S. Straub (2008). Renegotiation of concession contracts in Latin America. Evidence from the water and transport sector. International Journal of Industrial Organization 26, 421-442.

Hart, O. (2003). Incomplete contracts and public ownership: Remarks, and an application to public-private partnerships. The Economic Journal 113(486), C69-C76.

Hart, O. and J. Moore (1988). Incomplete contracts and renegotiation. Econometrica 56(4), $755-785$.

Hart, O., A. Shleifer, and R. W. Vishny (1997). The proper scope of government: Theory and an application to prisons. Quarterly Journal of Economics 112(4), 1127-1161.

Hefetz, A. and M. E. Warner (2012). Contracting or public delivery? the importance of service, market, and management characteristics. Journal of Public Administration Research 8 Theory 22(2), 289-317. 
Kwon, I. (2014). Motivation, discretion, and corruption. Journal of Public Administration Research 85 Theory Theory 24(3), 765-794.

Laakso, M. and R. Taagepera (1979). "Effective" number of parties: A measure with application to West Europe. Comparative Political Studies 12(1), 3-27.

Laffont, J.-J. and J. Tirole (1993). A Theory of Incentives in Procurement and Regulation. Cambridge, MA: MIT Press.

Levin, J. and S. Tadelis (2010). Contracting for government services: Theory and evidence from us cities. Journal of Industrial Economics 58(3), 507-541.

Liu, B.-C. and T. L.-P. Tang (2011). Does the love of money moderate the relationship between public service motivation and job satisfaction? the case of Chinese professionals in the public sector. Public Administration Review 71(5), 718-727.

Macaulay, S. (1963). Non-contractual relations in business: A preliminary study. American Sociological Review 28(1), 55-67.

Moszoro, M. W. and P. T. Spiller (2012). Third-party opportunism and the nature of public contracts. National Bureau of Economic Research, NBER Working Paper 18636.

Moszoro, M. W. and P. T. Spiller (2014). Third-party opportunism and the theory of public contracts: Operationalization and applications. In E. Brousseau and J.-M. Glachant (Eds.), The Manufacturing of Markets: Legal, Political and Economic Dynamics, Chapter 11, pp. 229-252. Florence: Cambridge University Press.

Moszoro, M. W. and P. T. Spiller (2016). Coase and the transaction cost approach to regulation. In C. Ménard and E. Bertrand (Eds.), The Elgar Companion to Ronald H. Coase, Chapter 19, pp. 262-275. Cheltenham, UK: Edward Elgar Publisher.

Moszoro, M. W. and P. T. Spiller (2019). Political contestability and public contracting. Journal of Public Economic Theory 21 (5), 945-966.

Moszoro, M. W., P. T. Spiller, and S. Stolorz (2016). Rigidity of public contracts. Journal of Empirical Legal Studies 13(3), 396-427.

NAO (2003). PFI: Construction performance. Technical report, National Audit Office.

Saussier, S. (2000). Transaction costs and contractual incompleteness: The case of Électricité de France. Journal of Economic Behavior and Organization 42(2), 189-206. 
Schwartz, A. and J. Watson (2012). Conceptualizing contractual interpretation. Research Paper 447, Yale Law \& Economics.

Spiller, P. T. (2008). An institutional theory of public contracts: Regulatory implications. National Bureau of Economic Research, NBER Working Paper 14152.

Spiller, P. T. (2009). An institutional theory of public contracts: Regulatory implications. In C. Ménard and M. Ghertman (Eds.), Regulation, Reregulation, Reregulation: Institutional Perspectives, Chapter 3, pp. 45-66. Edward Elgar Publishing.

Spiller, P. T. (2010). Regulation: A transaction cost perspective. California Management Review 52(2), 147-158.

Spiller, P. T. (2013). Transaction cost regulation. Journal of Economic Behavior E Organization 89, 232-242.

Williamson, O. E. (1999). Public and private bureaucracies: A transaction cost economics perspectives. Journal of Law, Economics, ES Organization 15(1), 306-342.

Wright, B. E. (2007). Public service and motivation: Does mission matter? Public administration review 67(1), 54-64. 


\section{Appendix A Proofs}

\section{Appendix A.1 Proof of Proposition $1-$ Contractual Completeness}

Let $\mathbb{S}$ be a compact space with full-support (continuous) and $s_{1,2, \ldots}$ be the possible states of the world uniformly or normally distributed with mean $\bar{s}$ (reference point).

Let $\mu$ be the probability space such that:

$$
\mu\left(\mathbb{X}^{C}\right)=\pi\left(x^{C}\right)^{n}=\mathbb{E}(\operatorname{Pr}[\nu=1])
$$

where $x^{c}$ is the maximum distance between the reference point $\bar{s}$ and the states of the world contemplated in the contract space $\mathbb{X}^{C}$, and $n$ the contract dimensionality.

The expected probability of contract continuation probability $\mathbb{E}(\operatorname{Pr}[\nu=1])$-i.e., that the

realized state of the world $s$ is within $\mathbb{X}^{C}$-rises in contractual completeness $x^{c}$ and the contractual space $\mathbb{X}^{C}$ :

$$
\frac{\partial \mathbb{E}(\operatorname{Pr}[\nu=1])}{\partial x^{C}}>0
$$

In vernacular terms, the probability of hitting the target rises with the size of the target.

\section{Appendix A.2 Proof of Proposition $2-$ Contractual Flexibility}

$X^{F}$ is a multiple of $X^{C}$ : i.e., $\mathbb{X}^{F}=\left[0, \phi x^{C}\right]$, with scalar $\phi>1$. Thus, analogously to the proof of Proposition 1:

$$
\frac{\partial \mathbb{E}(\operatorname{Pr}[\nu=1])}{\partial x^{F}}>0
$$

I.e., hitting the frame of the target is also considered to be a "hit" for contract continuation.

\section{Appendix A.3 Proof of Proposition 3 Contractual Rididity}

Holding $x^{P}$ constant, an expansion of the probability space $\mu\left(\mathbb{X}^{C}\right)$ expands the probability space $\mu\left(\mathbb{X}^{C}-\mathbb{X}^{P}\right)=1-\mathbb{E}(\operatorname{Pr}[\lambda=1])$. Therefore,

$$
\frac{\partial \mathbb{E}(\operatorname{Pr}[\lambda=1])}{\partial x^{C}}<0
$$

I.e., keeping the political tolerance for deviations from the reference point constant, the probability of hitting the "donut" space between the actual contractual terms and the politically tolerated states of the world increases. A risk-averse public agent will increase political safety by increasing contractual rigidity. 


\section{Appendix A.4 Proof of Proposition $4-$ Political Tolerance}

Conversely to proof of Proposition 3 , holding $x^{C}$ constant and expanding the probability space $\mu\left(\mathbb{X}^{P}\right)$ shrinks the probability space $\mu\left(\mathbb{X}^{C}-\mathbb{X}^{P}\right)=1-\mathbb{E}(\operatorname{Pr}[\lambda=1])$. Therefore,

$$
\frac{\partial \mathbb{E}(\operatorname{Pr}[\lambda=1])}{\partial x^{P}}>0
$$

I.e., political tolerance increases the space of hits considered to be close enough to the reference point. 
Table 2: This table presents descriptive statistics of the variables used in the empirical tests. Frequency of renegotiations is the number of formal contract amendments divided by the duration of the contract. Contractual rigidity is the normalized measure of procedural terms in a contract. Public is a dummy variable equal to 1 when the contract was signed between a municipality and a private-sector contractor, and zero when the contract was signed between two private-sector parties. NEP is the number of equal parties in a municipal election race defined as the inverse of the sum of squared vote shares for each party. NREP is the number of equal opposition parties in a municipal election race defined as the inverse of the sum of squared vote shares for each opposition party, i.e., without the winning party vote share. Provision-of-services is a dummy variable equal to 1 when the contract is for short-term contracts that do not require investments, and zero when the contract is a medium- or long-term operating contract where the investor bears demand risk and collects user fees. Contract duration is the intended duration of the contract in years. Places is the number of parking units in thousands. Corruption is the number of cases of corruption implicating a municipal official in the three years preceding the date the contract was signed, registered by from Transparency International France. Renewed is a dummy variable equal to zero for original contracts and 1 for renewed (follow-up) contracts. Inhabitants is the natural logarithm of the number of inhabitants in the municipality. Left-wing mayor and right-wing mayor are dummy variables if the incumbent mayor at the time of renegotiation was left-wing or right-wing leaning, respectively. Experience is the difference between the dates that the contract was signed and their first contract. Past contracts is the number of all common contracts up to the observation date. Year of contract signing is the year the contract was signed.

\begin{tabular}{lcccc}
\hline Variables & Mean & Std & Min & Max \\
\hline Frequency of renegotiations & 0.22 & 0.36 & 0 & 2 \\
Contractual rigidity & 1.90 & 18.06 & -27.62 & 73.62 \\
Public & 0.84 & 0.36 & 0 & 1 \\
NEP & 2.93 & 0.86 & 1 & 4.82 \\
NREP & 2.23 & 0.38 & 1.51 & 3.11 \\
Provision-of-services & 0.47 & 0.50 & 0 & 1 \\
Contract duration & 12.81 & 8.36 & 1 & 33 \\
Places (thousand) & 0.20 & 1.42 & 0.00 & 24.16 \\
Corruption & 1.88 & 1.09 & 0 & 9.75 \\
Renewed & 0.19 & 0.39 & 0 & 1 \\
Inhabitants & 10.51 & 1.39 & 8.09 & 14.08 \\
Left-wing mayor & 0.11 & 0.31 & 0 & 1 \\
Righ-wing mayor & 0.33 & 0.47 & 0 & 1 \\
Experience & 8.46 & 11.54 & 0 & 43 \\
Past contracts & 2.99 & 9.23 & 0 & 68 \\
Year of contract signing & 2002 & 6.54 & 1985 & 2009 \\
\hline
\end{tabular}


Table 3: This table presents results of OLS regressions of the determinants of the frequency of contract renegotiations. The dependent variable is the frequency of contract renegotiations defined as the number of formal contract amendments divided by the duration of the contract. Public is a dummy variable equal to 1 when the contract was signed between a municipality and a private-sector contractor, and zero when the contract was signed between two private-sector parties. Provision-of-services is a dummy variable equal to 1 when the contract is for short-term contracts that do not require investments, and zero when the contract is a medium- or long-term operating contract where the investor bears demand risk and collects user fees. Contract duration is the intended duration of the contract in years. Places is the number of parking units in thousands. Corruption is the number of cases of corruption implicating a municipal official in the three years preceding the date the contract was signed, registered by from Transparency International France. Renewed is a dummy variable equal to zero for original contracts and 1 for renewed (follow-up) contracts. Other controls include number of inhabitants, political leaning of the city's mayor, experience, past contractual relationship, and year fixed effects. The contract sample period is 1963-2008 and election data period is 1983-2008. Heteroskedasticity-robust $t$-statistics clustered at the municipal level are reported in parenthesis; ${ }^{*}$ denotes significance at $10 \%,{ }^{* *}$ significance at $5 \%$, and ${ }^{* * *}$ significance at $1 \%$.

\begin{tabular}{lccc}
\hline & $(1)$ & $(2)$ & $(3)$ \\
\hline Public & $0.071^{*}$ & $0.071^{*}$ & $0.130^{* *}$ \\
& $(0.043)$ & $(0.043)$ & $(0.058)$ \\
Provision-of-services & & 0.053 & 0.036 \\
& & $(0.045)$ & $(0.050)$ \\
Contract duration & & -0.002 & -0.004 \\
& & $(0.003)$ & $(0.004)$ \\
Places & & $-0.013^{* * *}$ & -0.005 \\
Corruption & & $(0.003)$ & $(0.004)$ \\
& & -0.001 & -0.008 \\
Renewed & & $-0.017)$ & $(0.019)$ \\
& & $(0.040)$ & $(0.043)$ \\
Controls & No & No & Yes \\
\hline Observations & 293 & 293 & 293 \\
R-squared & 0.015 & 0.066 & 0.094 \\
\hline
\end{tabular}


Table 4: This table presents results of 2SLS regressions of the determinants of the frequency of contract renegotiations instrumenting contractual rigidity with measures of political contestability. The dependent variable is the frequency of contract renegotiations defined as the number of formal contract amendments divided by the duration of the contract. Provision-of-services is a dummy variable equal to 1 when the contract is for short-term contracts that do not require investments, and zero when the contract is a medium- or long-term operating contract where the investor bears demand risk and collects user fees. Contract duration is the intended duration of the contract in years. Places is the number of parking units in thousands. Corruption is the number of cases of corruption implicating a municipal official in the three years preceding the date the contract was signed, registered by from Transparency International France. Renewed is a dummy variable equal to zero for original contracts and 1 for renewed (follow-up) contracts. As instruments of contractual rigidity we use: Public, NEP, and NREP, where the baseline is private contracts. Public is a dummy variable equal to 1 when the contract was signed between a municipality and a private-sector contractor, and zero when the contract was signed between two private-sector parties. NEP is the number of equal parties in a municipal election race defined as the inverse of the sum of squared vote shares for each party. NREP is the number of equal opposition parties in a municipal election race defined as the inverse of the sum of squared vote shares for each opposition party, i.e., without the winning party vote share. Other controls include number of inhabitants, political leaning of the city's mayor, experience, past contractual relationship, and year fixed effects. The contract sample period is 1963-2008 and election data period is 1983-2008. Heteroskedasticity-robust $t$-statistics clustered at the municipal level are reported in parenthesis; ${ }^{*}$ denotes significance at $10 \%,{ }^{* *}$ significance at $5 \%$, and ${ }^{* * *}$ significance at $1 \%$.

\begin{tabular}{|c|c|c|c|c|c|c|}
\hline & \multicolumn{2}{|c|}{$(1)$} & \multicolumn{2}{|c|}{$(2)$} & \multicolumn{2}{|c|}{$(3)$} \\
\hline & First stage & IV & First stage & IV & First stage & IV \\
\hline Contractual rigidity & & $\begin{array}{c}0.015^{* *} \\
(0.008)\end{array}$ & & $\begin{array}{c}0.011^{* *} \\
(0.005)\end{array}$ & & $\begin{array}{l}0.013^{*} \\
(0.008)\end{array}$ \\
\hline Provision-of-services & $\begin{array}{c}-10.033^{* * *} \\
(2.507)\end{array}$ & $\begin{array}{l}0.162^{*} \\
(0.093)\end{array}$ & $\begin{array}{c}-10.019^{* * *} \\
(2.469)\end{array}$ & $\begin{array}{c}0.127 \\
(0.081)\end{array}$ & $\begin{array}{c}-10.226^{* * *} \\
(2.803)\end{array}$ & $\begin{array}{c}0.147 \\
(0.095)\end{array}$ \\
\hline Contract duration & $\begin{array}{c}-0.052 \\
(0.160)\end{array}$ & $\begin{array}{c}-0.007^{*} \\
(0.004)\end{array}$ & $\begin{array}{c}-0.102 \\
(0.157)\end{array}$ & $\begin{array}{c}-0.006^{*} \\
(0.003)\end{array}$ & $\begin{array}{l}-0.119 \\
(0.179)\end{array}$ & $\begin{array}{c}-0.008^{*} \\
(0.004)\end{array}$ \\
\hline Places & $\begin{array}{c}2.630^{* * *} \\
(0.754)\end{array}$ & $\begin{array}{c}-0.044 \\
(0.028)\end{array}$ & $\begin{array}{c}2.616^{* * *} \\
(0.746)\end{array}$ & $\begin{array}{c}-0.034^{* *} \\
(0.015)\end{array}$ & $\begin{array}{c}11.760^{* * *} \\
(4.498)\end{array}$ & $\begin{array}{c}-0.199 \\
(0.146)\end{array}$ \\
\hline Corruption & $\begin{array}{c}0.276 \\
(0.929)\end{array}$ & $\begin{array}{l}-0.013 \\
(0.024)\end{array}$ & $\begin{array}{c}0.318 \\
(0.922)\end{array}$ & $\begin{array}{l}-0.011 \\
(0.020)\end{array}$ & $\begin{array}{c}0.194 \\
(0.972)\end{array}$ & $\begin{array}{l}-0.004 \\
(0.024)\end{array}$ \\
\hline Renewed & $\begin{array}{l}-1.067 \\
(2.634)\end{array}$ & $\begin{array}{c}-0.216^{* * *} \\
(0.069)\end{array}$ & $\begin{array}{l}-0.796 \\
(2.607)\end{array}$ & $\begin{array}{c}-0.221^{* * *} \\
(0.057)\end{array}$ & $\begin{array}{l}-1.083 \\
(2.937)\end{array}$ & $\begin{array}{c}-0.171^{* *} \\
(0.072)\end{array}$ \\
\hline Controls & Yes & Yes & Yes & Yes & Yes & Yes \\
\hline \multicolumn{7}{|c|}{ First-stage instruments } \\
\hline Public & $\begin{array}{c}11.569^{* * *} \\
(3.477)\end{array}$ & & & & & \\
\hline NEP & & & $\begin{array}{c}-3.017^{*} \\
(1.651)\end{array}$ & & & \\
\hline NEP $\times$ Public & & & $\begin{array}{c}4.287^{* * *} \\
(0.998)\end{array}$ & & & \\
\hline NREP & & & & & $\begin{array}{c}-1.727 \\
(3.331)\end{array}$ & \\
\hline NREP $\times$ Public & & & & & $\begin{array}{c}4.835^{* * *} \\
(1.579)\end{array}$ & \\
\hline F-statistics & 11.07 & - & 9.25 & - & 4.89 & - \\
\hline$p$-value & 0.001 & - & 0.001 & - & 0.008 & - \\
\hline Observations & 293 & 293 & 293 & 293 & 259 & 259 \\
\hline R-squared & 0.206 & 0.426 & 0.226 & 0.196 & 0.183 & 0.313 \\
\hline
\end{tabular}

